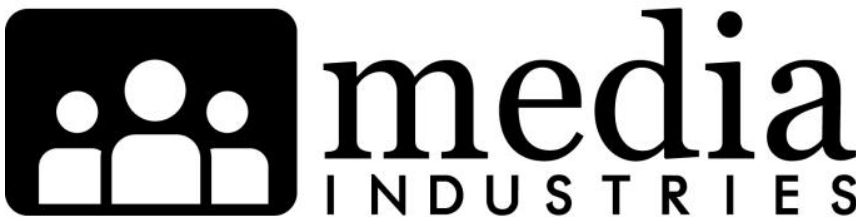

\section{The Impact of Working Conditions and Personality Traits on the Job Satisfaction of Media Professionals}

\author{
M. Bjørn von Rimscha ${ }^{1}$ \\ Johannes Gutenberg-University Mainz \\ b.vonrimscha [AT] uni-mainz.de
}

\begin{abstract}
:
This article uses the happy-productive worker thesis as a starting point for assessing the chances that a media system is performing well. Personality traits, work conditions, and job-satisfaction levels of individuals from different media occupations in Switzerland $(N=259)$ were collected using standardized instruments from personnel psychology. Media workers more distanced from actual media production are more satisfied with their jobs than the working population, while those closer to production are less satisfied. A regression analysis identifies autonomy as the most important driver of job satisfaction for "media producers," while "media seller's" satisfaction is driven by the match of their work with personality extroversion and the perception of adequate compensation. This suggests that the drivers of job satisfaction differ according to the actual job role in the media industry.
\end{abstract}

Keywords: Switzerland, Labor, Production, Management, Identity

Technological, economic, and regulatory changes in recent years have changed not only the structure of the media industry but also the job roles of media professionals in different production-related occupations. Cost cutting in newspaper firms has turned many permanent employees into freelancers who must be creative as they learn to tackle "forced entrepreneurialism" 2 at the same time. Likewise, in audiovisual entertainment, producers increasingly require marketing skills because broadcasters no longer fully finance commissioned series. ${ }^{3}$ To some extent, recent changes in the media industry can be described as a process of further commodification of the commercialized media workplace where commercial pressures are increasingly dominating content decisions. ${ }^{4}$ Thus, potentially, some of the alienated media professionals ${ }^{5}$ are ever more estranged from the work they are doing. Media professionals regularly show a high level of intrinsic motivation for their emotional and affective labor. ${ }^{6}$ They "care about their product" 7 and are often even willing to perform unpaid labor to gain access to meaningful jobs. ${ }^{8}$

Therefore, they most likely differ substantially from the general working population in terms of their personalities. Changes in the industry add to the problem of specific requirements in the 
job profiles of creative professionals. Individuals' personalities and skill sets might have matched job requirements when they first entered the business, but some might not fit anymore. The economic "creative destruction" 9 deriving from digitization and subsequent commodification 10 could also damage media professionals' job satisfaction because these advances do not offer the increased efficiency that theoretically accompanies creative destruction from an economic welfare perspective. Barriers of entry are reduced, but at the cost of precarious working conditions ${ }^{11}$ and reduced creative freedom. ${ }^{12}$ This is not only relevant for individual media professionals but also for society. If the happy-productive worker thesis ${ }^{13}$ holds true, society relies on motivated and satisfied media workers to produce useful and relevant media content catered to an informed and responsible society.

Loosely following the concept of effort-reward imbalance, ${ }^{14}$ this article assumes that the fit between personality traits and job requirements is a foundational aspect of job satisfaction and subsequently of the quality of output. There are a number of definitions and conceptualizations formed in an effort to describe what is understood to be personality. This article is informed by the five-factor model, ${ }^{15}$ which is based in the trait-psychology tradition. This model claims that there are consistent and enduring individual differences in ways of thinking, feeling, and acting that can be measured by questionnaires. The five factors were derived from factor analysis of numerous measurements of different traits and represent the highest aggregate of the diverse traits:

- Neuroticism (sensitive/nervous vs. secure/confident)

- Extroversion (outgoing/energetic vs. solitary/reserved)

- Openness to experience (inventive/curious vs. consistent/cautious)

- Agreeableness (friendly/compassionate vs. analytical/detached)

- Conscientiousness (efficient/organized vs. easygoing/careless)

Personality traits do not change much for working-age adults, 16 so changes in job requirements should have a strong influence on job satisfaction.

On the one hand, since the early Hawthorne studies, ${ }^{17}$ research at the intersection of psychology, management, and health has addressed questions of how to select the right personnel and how to ensure that the relationship is productive while maintaining satisfaction and health. On the other hand, media and communication studies have often addressed the issue of journalist satisfaction 18 and whether the media addresses the needs of society. However, at present, both strands of literature (introduced in the first section of this paper) have neglected each other and have failed to build on one another's insights. This study tries to fill this gap by applying standardized instruments from personnel psychology to different media occupations as described in the second section. Because no historical data is available, it isn't possible to trace changes concerning the fit between personality traits and job requirements directly. However, a cross-sectional analysis of different media occupations also allows for some conclusions since they have been variably affected by media change. The model is tested with data from a standardized survey of 259 media professionals in Switzerland. The results allow for two main conclusions discussed in the final section of this paper: First, it is possible to identify media occupations that have low job satisfaction levels and thus risk impeding quality output. This would be a possible starting point for pro-quality regulatory measures focusing on the individual. Second, comparisons between different occupations allow for preliminary 
assumptions about the effects of media change on media production at the individual level. This could be the starting point for further research on the interaction between media change, media professionals and media quality, albeit from a commercial or normative perspective.

\section{How Happiness Makes Workers More Productive}

The relationship between job satisfaction and job performance has been extensively studied in organizational behavior research, usually in relation to the happy-productive worker hypothesis. ${ }^{19}$ The underlying assumption in these studies is the idea that happier employees will be more productive. Of course happy is a rather ill-defined term that can have many meanings. Frequently, happiness is interpreted as a trait that is constant in a given timeframe. Thus, happiness is translated as satisfaction or, in a narrow sense, job satisfaction ${ }^{20}$ and, in a wider sense, psychological well-being. ${ }^{21}$ Alternatively, some studies interpret happiness as an emotional state or, more precisely, positive affect. ${ }^{22}$ There is an ongoing debate about which measures are most suitable, whether effects are to be found immediately or intertemporally, ${ }^{23}$ and whether the happy-productive worker thesis is an overrated common-sense theory. ${ }^{24}$ However, two meta-analyses condensing the results of other studies have found a moderate mean correlation between satisfaction and performance of $r=0.31$ and $r=0.30 .{ }^{25}$

Thus, the question arises as to which factors inform job satisfaction. Certainly, some factors are objective qualities of the workplace, such as job characteristics, ${ }^{26}$ but individual predispositions also play their part. Barrick and Mount ${ }^{27}$ and Hogan and Holland ${ }^{28}$ showed in their respective meta-analyses that personality traits have an influence on performance. According to Barrick and Mount, conscientiousness is an especially robust predictor of performance across different measures and occupations. By contrast, another meta-analysis ${ }^{29}$ found that only extroversion (positive) and neuroticism (negative) are important and generalizable predictors of performance. More importantly, all three aforementioned studies found that the influences of different personality traits vary between different occupations, which suggests a match between personality traits and job requirements is a necessary component of job satisfaction. Extroversion and agreeableness could, for example, predict job performance for salespeople and managers-occupations that involve frequent interaction or cooperation with others - but not for skilled workers or police officers. ${ }^{30}$ Similarly, and more recently, Rauch and Frese showed that for entrepreneurs, personality traits matching their tasks led to higher rates of success. ${ }^{31}$ Most likely, this is a general pattern, although so far no study has investigated beneficial personality traits in media occupations.

To some extent, studies dealing with creative professionals are transferable: positive emotions have been shown to contribute to creative performance. ${ }^{32}$ Some studies have referred to the fact that creative production is regularly done in teams of devoted and intrinsically motivated individuals who might have their own agendas. Robert and Cheung have found a negative relationship between group conscientiousness and group performance on creative tasks, ${ }^{33}$ thus qualifying Barrick and Mount's results that showed conscientiousness as a universal predictor of success. Research on team performance suggests that the diversity within a team contributes more to the performance than the addition of individuals with similar personality traits, ${ }^{34} \mathrm{a}$ finding that supports the motley-crew property of creative production put forth by Caves. ${ }^{35}$ Moreover, Strickland and Towler suggest that inspiration works best when personality differences are strong between leaders and subordinates. ${ }^{36}$

Usually, people choose occupations that are in line with their personalities and avoid those that do not suit them. An introverted person, for instance, is unlikely to become a TV presenter. If 
the dominant logic within an industry changes due to technological or organizational developments, job roles will change as well. This might mean that individuals who initially chose jobs and organizations fitting their personalities ${ }^{37}$ might find themselves in positions in which their personalities are at odds with new demands. Williamson, Lounsbury, and Han could show this for engineers who need to develop an entrepreneurial mindset and sales skills. ${ }^{38}$ Digitization has drastically changed some media occupations. Fifteen year ago, a photojournalist spent much of his or her time performing the physical task of developing the pictures - a widely obsolete undertaking today. In entertainment production, broadcasters have outsourced many tasks to independent producers, so the job requires more entrepreneurial skills today. ${ }^{39}$ Chances are that some individuals have problems adapting to the new demands of the workplace, resulting in decreased job satisfaction and, subsequently, decreased quality of output.

In the media context, the question of whether job satisfaction has an impact on the quality of the output has never really been tested. Stamm and Underwood showed that a journalist's perception of increasing or decreasing newspaper quality had an impact on that person's job satisfaction. ${ }^{40}$ However, they did not test whether this job satisfaction in turn had an impact on quality independent from the newsroom policies they were studying.

Research on job satisfaction in the context of the media industry has by and large neglected existing work in the field of occupational psychology and medicine, creating ad hoc measures instead of using existing scales. ${ }^{41}$ The studies of Norwegian workaholic journalists ${ }^{42}$ and the psychological health of Nigerian journalists ${ }^{43}$ are rare exceptions. Personality traits of media professionals have thus far not been analyzed as a factor of job satisfaction in the media industry.

While there is much discussion in occupational and organizational psychological literature on measuring "happiness" (trait vs. state), the outcome variable "performance" has never been questioned. This might be accurate for manual tasks, or for commercial occupations, where performance can be measured in monetary value. In the media industry, however, the performance variable is more ambiguous, since media not only serves an economic function but also cultural, societal and political functions. ${ }^{44}$ Some performances might serve functions differently at varying levels of quality. Thus, measuring the operationalization of performance in terms of, for example, number of photographs taken or number of listeners gained always captures performance in a very narrow sense by aligning it to just one function of the media.

This study does not discuss the meaning of job performance of media professionals from a societal perspective (normative quality of the output) since this would mean subsuming the decade-long discussion on media quality. ${ }^{45}$ However, it does introduce standard measures into the field of communicator studies that help apply research on job satisfaction of media professionals to the general literature on job satisfaction. It will also show that different media occupations feature different levels of satisfaction and require different personality traits.

\section{Research Questions}

The aim of this study is twofold: First, it will describe the differences between various media occupations and the working population in terms of job satisfaction and personality. While media professionals are regularly described as individuals who are intrinsically motivated and at times display an accentuated creative personality, their actual personality in psychological terms has never been measured. Thus, the first set of research questions is: 
- How do media occupations differ from the working population and from each other in terms of personality traits? (RQ1a)

- How do media occupations differ from the working population and from each other in terms of their levels of job satisfaction? (RQ1b)

Second, existing studies on work satisfaction and personality ${ }^{46}$ are replicated in the media context in order to gauge the relative influence of personality traits and working conditions. Thus, the second question is:

- To what extent do personality traits and working conditions explain job satisfaction in different media occupations? (RQ2)

\section{Method}

An online survey of German-speaking media professionals in Switzerland from seven different occupations was conducted in the spring of 2013. For comparisons to the working population, data from the Swiss Household Panel 47 (SHP) was used. To contextualize this study, a description of the Swiss media industry is necessary. The Swiss media market is small and fairly concentrated. Only three publishers dominate the newspaper industry: two family-owned companies (Tamedia and Ringier) and one loosely connected to a political party (NZZ). The audiovisual sector is dominated by the public-service broadcaster both in terms of audience share and in term of commissioning. Therefore, although fairly concentrated, the Swiss media market is still not as commercialized as media markets in many other countries.

\section{Measures}

Two measures of satisfaction were used to differentiate between a general assessment and one focused on the workplace.

General satisfaction with life was measured with the German version ${ }^{48}$ of the Satisfaction with Life Scale (SWLS) by Diener et al. ${ }^{49}$ It contains five items which are rated on a 5-point Likert scale and are combined to a sum index $(\alpha=.89)$. In the SHP, general satisfaction with life is measured using just one item.

Job satisfaction was measured using the appropriate subscale of the German "questionnaire on life satisfaction." 50 It contains seven items on job satisfaction, which are rated on a 7-point Likert scale and combined to a sum index $(\alpha=.85)$. In the SHP, five items are used $(\alpha=.81)$.

In terms of working conditions, this study concentrates on selected items that were shown to be important in other studies. ${ }^{51}$ Two aspects of the freedom to create were captured: in a positive perspective, it is the level of autonomy that media professionals have in choosing when and how to do their jobs. Autonomy was measured using relevant items from the German version ${ }^{52}$ of the Work Design Questionnaire. ${ }^{53}$ There were two items per autonomy dimension (planning, deciding, method), which were combined to a mean index $(\alpha=.86)$. From a negative perspective, the freedom to create can turn into a burden and lead to overcommitment. This measure captures the degree to which the intrinsic motivation of a media professional leads to a situation in which he or she takes more responsibility for the result than would be adequate and healthy. Overcommitment was measured using the short version of the Effort-Reward-Imbalance model. ${ }^{54}$ There were six items measured on a 4-point Likert scale and combined to a sum index $(\alpha=.79)$. Furthermore, the effort-reward ratio connects intrinsic and extrinsic motivators by relating the self-reported effort of an individual to the perceived rewards. In that sense, it can be 
regarded as a perceived exploitation index. The effort-reward ratio was taken from the same source. It is a ratio of an effort to a reward index. Effort was a sum index of three items measured on a 4-point Likert scale $(\alpha=.77)$. Reward was a sum index of seven items measured on a 4 -point Likert scale $(\alpha=.81)$.

The effects of working conditions can be expected to be moderated by the personality traits of the surveyed individuals. Therefore, the personality traits were measured using a short version of the Big Five inventory in German. ${ }^{55}$ Each personality trait was measured by rating four (five for openness) items on a 5-point Likert scale. While the short version allows for short online questionnaires and thus helps to reduce invalidated results, it offers a lower reliability. For each trait, mean indices are calculated: Neuroticism $(\alpha=.70)$, Extroversion $(\alpha=.80)$, Openness $(\alpha=$ .65), Agreeableness $(\alpha=.62)$, and Conscientiousness $(\alpha=.69)$. In the SHP, the personality indices are calculated based on two items for each trait.

\section{Sample}

Since the concept of personality traits has not been widely used in research on media occupations, there are no existing studies to build on when choosing a sample. Seven media occupations that differ in terms of work profiles and the potentially beneficial personality traits considered plausible were selected. We aimed for a large variety in the sample as a whole, while ensuring homogeneity within the occupations. General journalists were not included in the sample because there is too much variety within this occupation to make it a useful category. The association of Swiss journalists (Impressum) represents investigative journalists at quality newspapers as well as fashion journalists at women's magazines or cartoonists at satire magazines. The differences between such diverse occupations within a group would supersede differences between the groups.

1. Foreign correspondents presumably need to be above average in terms of openness and need to remain detached and analytical. Therefore they should score lower on the agreeableness scale. Quantitative studies of foreign correspondents to date have focused on sociodemographics or journalistic norms; ${ }^{56}$ however, ethnographic case studies support the notion that individuals who are open-minded and adaptable without becoming committed make good foreign correspondents. ${ }^{57}$

2. Photojournalists presumably are more likely to be introverted observers or possibly even slightly neurotic artists. A study by Freeman described the personality of awardwinning photojournalists as generally intuitive, although his respondents were divided into two equally big groups in terms of their extroversion and introversion. 58

3. Entertainment producers presumably are operative managers with stereotypical extroversion and low agreeableness. While Grindstaff found these very characteristics among the talk show producers she studied, she also found a certain level of selfreflection. ${ }^{59}$

4. Entertainment editors presumably need above-average agreeableness when balancing art and ratings. This group has not been analyzed before, and it is therefore one of the aims of this study to differentiate between different occupations in the entertainment sector.

5. Presenters presumably need to be especially open and extroverted. Patrona even describes an "intrinsically synthetic" personality where openness and extroversion serve 
as a means to sell the show. ${ }^{60}$ However, in a slightly different context Greengross and Miller point out the need to differentiated between stage personas and their true personality traits. ${ }^{61}$

6. Publishers presumably resemble managers, with equally high extroversion levels. Underwood has described them as almost antagonists of journalists ${ }^{62}$ and thus we should expect considerable differences for this group.

7. Marketing directors resemble the sales people in the study of Barrick and Mount, ${ }^{63}$ and thus presumably score lowest on neuroticism and highest on extroversion.

Furthermore, these media occupations differ in terms of how much they have been affected by digitization. The job of a photojournalist has changed substantially, while the publisher's has changed to a lesser extent. The publication itself might have changed a lot, but the characteristics ${ }^{64}$ of the publisher's job have remained largely the same.

The sampling is based on the membership list of the respective associations in Germanspeaking Switzerland. Photojournalists have an occupational union with individual members. For the other occupations, a two-step approach was followed where associations were first used to identify the organizations and then the respective individuals were researched within the organization, both permanent staff and freelancers.

Table 1 provides an overview of the sample and the response rates.

\begin{tabular}{llcc}
\hline Table 1. Sampled Media Occupations & & & \\
\hline Occupation & Universe & Population & Response Rate \\
\hline Photojournalists & $\begin{array}{l}\text { German speakers in the Swiss photojournalist } \\
\text { association }\end{array}$ & 180 & $35 \%$ \\
\hline $\begin{array}{l}\text { Entertainment } \\
\text { editors }\end{array}$ & $\begin{array}{l}\text { All German-speaking program editors at Swiss } \\
\text { TV broadcasters and movie distributors }\end{array}$ & 56 & $24 \%$ \\
\hline Presenters & $\begin{array}{l}\text { All presenters listed on the websites of all } \\
\text { licensed or registered radio or TV broadcasters }\end{array}$ & 283 & $27 \%$ \\
\hline $\begin{array}{l}\text { Entertainment } \\
\text { producers }\end{array}$ & $\begin{array}{l}\text { All German-speaking producers working in } \\
\text { member companies of the four relevant } \\
\text { associations }\end{array}$ & 198 & $21 \%$ \\
\hline $\begin{array}{l}\text { Foreign } \\
\text { correspondents }\end{array}$ & $\begin{array}{l}\text { All Swiss-German news organizations with } \\
\text { foreign correspondents }\end{array}$ & 68 & $30 \%$ \\
\hline $\begin{array}{l}\text { Publishers of all German-language newspapers } \\
\text { who are members of the newspaper } \\
\text { association }\end{array}$ & 109 & $25 \%$ \\
\hline $\begin{array}{l}\text { Marketing directors of all German-speaking } \\
\text { directors }\end{array}$ & \begin{tabular}{l} 
media organizations with national sales \\
\hline
\end{tabular}
\end{tabular}

After controlling for incomplete or faulty questionnaires, the results are based on 259 respondents. For comparison with the general working population in Switzerland, the data from the SHP was used. The SHP is a survey panel representing the Swiss population carried out annually since 1999. Data are gathered from a random sample of private households interviewing all household members mainly by telephone. Out of the 10,470 individuals in the eleventh wave of the panel, information was used only for those 4,482 individuals who were 
(self-)employed at the time of the survey and living in German-speaking Switzerland. Information on personality traits was available only for a subsample $(n=243)$ since these measures were only recently introduced into the SHP questionnaire.

\section{Results}

\section{Personality Traits of Media Professionals}

Media professionals are significantly different from the working population in terms of their personalities. Since the sample sizes differ between the groups and equal variances cannot be assumed, a one-way ANOVA based on the Welch test ${ }^{65}$ and a Games-Howell post hoc test were used to test the group differences. All investigated media occupations show significantly lower neuroticism scores than the working population. Openness and conscientiousness are consistently higher and agreeableness consistently lower for media professionals when compared to the working population; however, not significantly so in all instances. Extroversion is higher for most media occupations; however, photojournalist and entertainment editors score lower than the working population. Overall, this result partially contrasts common assumptions about media professionals. Stereotypically, they are often described as creative professionals who are somewhat eccentric, and thus should score higher on neuroticism and lower on agreeableness and conscientiousness. The results therefore indicate that at least those media professionals who are members of their respective associations show personality traits that are indicative of professionals rather than eccentric creatives.

\begin{tabular}{|c|c|c|c|c|c|c|c|c|}
\hline & $\begin{array}{l}\frac{n}{. \frac{5}{2}} \\
\frac{0}{0} \\
\frac{5}{5} \\
\frac{0}{0} \\
\frac{1}{0} \\
\frac{c}{a} \\
\end{array}$ & 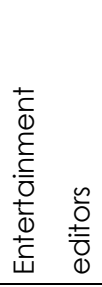 & 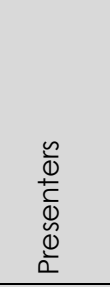 & 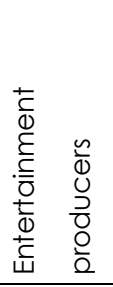 & 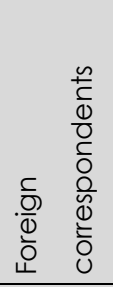 & $\begin{array}{l}\frac{\tilde{\omega}}{0} \\
\frac{c}{\underline{\underline{N}}} \\
\frac{0}{D} \\
0\end{array}$ & 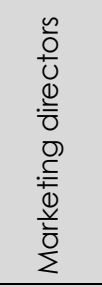 & 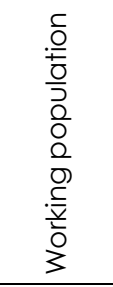 \\
\hline & (A) & (B) & (C) & (D) & (E) & $(F)$ & (G) & (H) \\
\hline & $n=63$ & $n=17$ & $n=68$ & $n=53$ & $n=14$ & $n=33$ & $n=11$ & $n=243$ \\
\hline Neuroticism & $2.77 \mathrm{DH}$ & $2.54^{\mathrm{H}}$ & $2.38^{H}$ & $2.28^{H}$ & $2.41^{\mathrm{H}}$ & $2.40^{\mathrm{H}}$ & $2.07^{H}$ & 3.59 \\
\hline Extroversion & $3.59 c$ & 3.44 & $4.07 \mathrm{H}$ & 3.87 & 3.96 & 4.01 & 4.34 & 3.65 \\
\hline Openness & $4.43^{F H}$ & $4.11^{\mathrm{H}}$ & $4.24^{\mathrm{H}}$ & $4.27^{\mathrm{H}}$ & 4.07 & $4.12^{\mathrm{H}}$ & 4.00 & 3.50 \\
\hline Agreeableness & $3.42^{\mathrm{H}}$ & 3.68 & 3.50 & $3.57 \mathrm{E}$ & $2.98^{\mathrm{H}}$ & 3.54 & 3.39 & 3.71 \\
\hline Conscientiousness & 4.08 & 4.21 & $4.14^{\mathrm{H}}$ & $4.19 \mathrm{H}$ & 4.13 & $4.25^{\mathrm{H}}$ & 4.39 & 3.89 \\
\hline
\end{tabular}

Note: Scale from 1 (low) to 5 (high). One-way ANOVA with Games-Howell post hoc test. Capital letters after scores indicate statistically significant differences of means between columns $(p<.05$, Welch $t$-test).

There are also notable differences between the occupations; however, due to the small number of cases, only a few of these differences are statistically significant (see table 2). Foreign correspondents score lowest on agreeableness, confirming their stereotype as self-absorbed and competitive. Photojournalism, the occupation that is probably the most "creative" among those sampled, has lower extroversion scores than even the general public, confirming the perception that members of this profession are introverted observers. Scoring highest on the openness and 
neuroticism scales is in keeping with the creative image of photojournalists. Extroversion is high for presenters, which comes as no surprise; however, it is even higher for marketing directors. Presumably, extroversion is even more important in face-to-face sales communication than in the parasocial setting of electronic media.

\section{Satisfaction Levels of Media Professionals}

Photojournalism, the occupation that has experienced the most dramatic change due to digitization, ${ }^{66}$ has the lowest satisfaction level (see table 3). However, one should not jump to conclusions concerning the effects of technological change: photojournalists also have the lowest income level and the highest job insecurity. Furthermore, the job of a foreign correspondent has changed considerably due to digitization of transmission and to the proliferation of online-media, ${ }^{67}$ apparently without detrimental effects on satisfaction. A longitudinal design is necessary to identify effects of digitization.

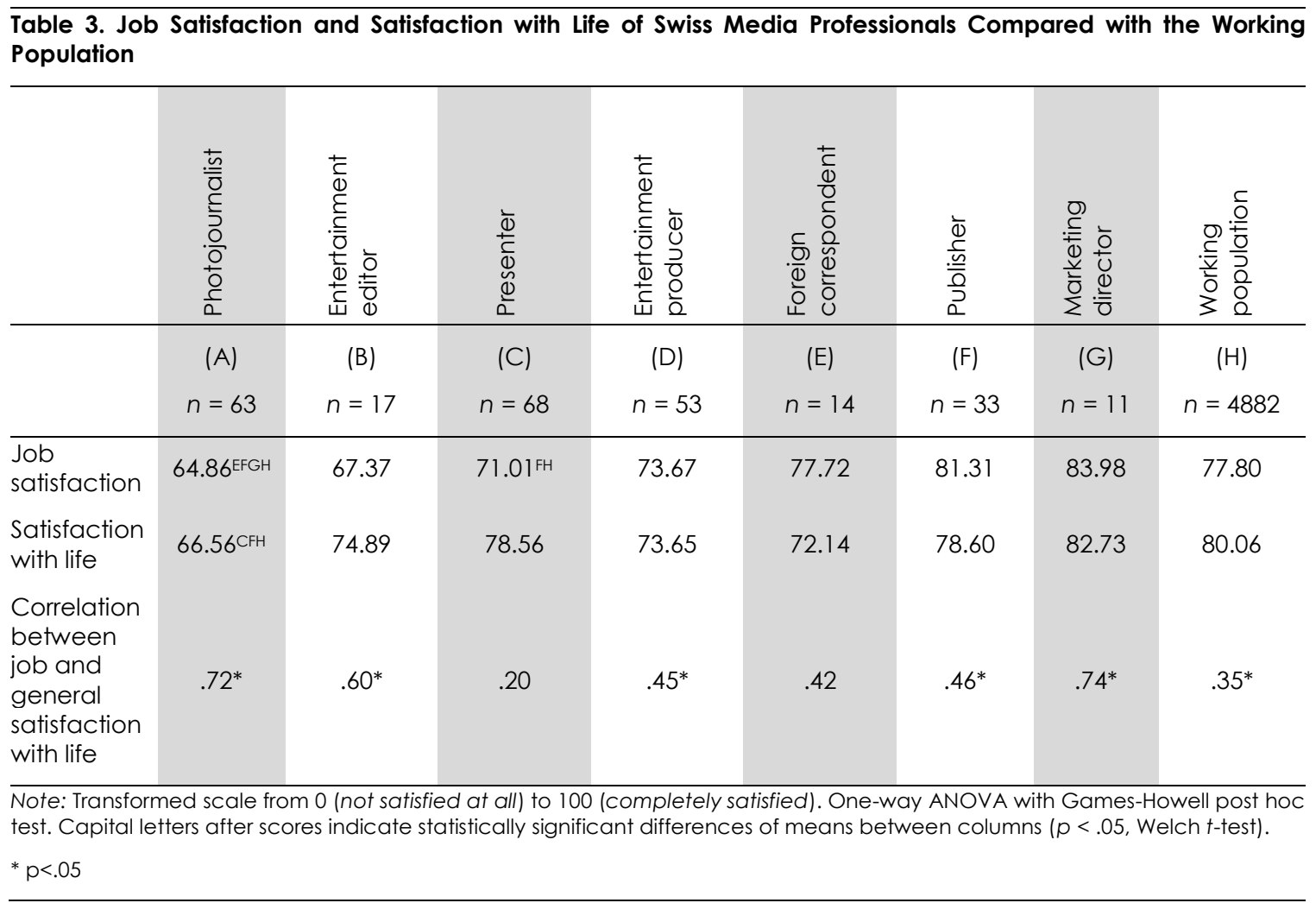

Five out of the seven occupations sampled are less satisfied with their jobs than the general working population, and photojournalists, entertainment editors, and presenters are significantly so. Only the two occupations most distanced from media content have satisfaction levels above the mean of the working population. Following the rationale of the happyproductive worker thesis, this is a disturbing result. Those selling the media are much happier than those producing it. If one further assumes that performance not only refers to efficiency but also to (normative) quality, these results suggest that the utility of media for society could be improved if content-creating media professionals were more satisfied with their work. A commercialized media system seems to satisfy "media sellers" more than "media producers." 
The comparison with the more general measure of satisfaction with life produces similar results. Publishers are below the mean of the working population, but still - together with the marketing directors-they are more satisfied than the other occupations. Foreign correspondents score lower, probably due to the rather stressful circumstances of the lifestyle they lead. Apparently, the influence of job satisfaction on life satisfaction in general differs between the sampled media occupations. This suggests differences in the relative importance of work in the conception of self. With the exception of presenters, all media occupations show a stronger correlation between job and life satisfaction than is found in the general working population.

Addressing the first research question, it can be stated that individuals in different media occupations differ in terms of their personality traits and in terms of their job satisfaction levels although the differences is less pronounced than expected. In comparison to the working population, media professionals are less neurotic but more open. In terms of satisfaction levels, the findings are mixed: while media professionals in some occupations are less satisfied with their jobs than the average of the general working population, the media occupations more distanced from the actual creation of content have above-average job satisfaction levels.

\section{Personality Traits, Working Conditions, and Job Satisfaction}

In the following section, the second research question on the connection between personality traits and working conditions on the one hand and job satisfaction on the other is addressed. The number of cases per occupation in the sample was too low to calculate a meaningful regression for each occupation separately. Therefore, the seven occupations in the sample were grouped according to their prime focus as indicated in the reported relative share of the categories of creative, operative and coordinative activities the respondents provided for a regular work day. Photojournalists, foreign correspondents, entertainment producers, entertainment editors and presenters together form the group "media producers" that is more involved in creative activities. Publishers and marketing directors form the group "media sellers" that is more involved in coordinative activities and selling the results of this processes. Operative activities did not discriminate between the groups.

Job satisfaction was explained using some basic demographic data, working conditions and personality traits in a regression model. Table 4 provides a descriptive overview of the variables used.

On average, media sellers are significantly more satisfied, have higher incomes, are older, enjoy more autonomy, and have higher extroversion scores than media producers. Media producers are significantly more open and tend to be are more overcommitted to their work.

Correlations between the explicatory variables imply that independence cannot be assumed. Therefore, a hierarchical regression model was used to assess the explanatory power of each block of variables and identify the relevant influencers. After the two demographic variables, the blocks were sorted according to the level of influence an individual can exert. Since personality traits cannot be changed, their influence should be more basal than the working conditions that can be changed by quitting an unsatisfactory job. Table 5 shows the results of the regressions for media producers and media sellers. 


\begin{tabular}{|c|c|c|c|c|}
\hline & \multirow{2}{*}{\multicolumn{2}{|c|}{$\begin{array}{c}\text { Media Producers } \\
\qquad n=202\end{array}$}} & \multirow{2}{*}{\multicolumn{2}{|c|}{$\begin{array}{c}\text { Media Sellers } \\
n=39\end{array}$}} \\
\hline & & & & \\
\hline & Mean & SD & Mean & SD \\
\hline Job satisfaction & 70.04 & 17.30 & $81.98^{*}$ & 11.98 \\
\hline Income (CHF) & 77100 & 39650 & $119500^{*}$ & 42480 \\
\hline Age & 41.79 & 11.31 & $47.98^{*}$ & 11.33 \\
\hline Gender (1=female) & .39 & .49 & .32 & .47 \\
\hline Overcommitment & 14.60 & 3.68 & $13.57^{\circ}$ & 3.59 \\
\hline Effort-reward ratio & .33 & .18 & .34 & .16 \\
\hline Autonomy & 4.11 & .69 & $4.74^{*}$ & .30 \\
\hline Neuroticism & 2.49 & .764 & 2.32 & .64 \\
\hline Extroversion & 3.82 & .76 & $4.09 *$ & .69 \\
\hline Openness & 4.28 & .52 & $4.09 *$ & .47 \\
\hline Agreeableness & 3.47 & .68 & 3.50 & .80 \\
\hline Conscientiousness & 4.14 & .57 & 4.28 & .54 \\
\hline \multicolumn{5}{|c|}{$*$ indicates differences between groups $p<.05$} \\
\hline \multicolumn{5}{|c|}{${ }^{\circ}$ indicates differences between groups $p<.1$} \\
\hline
\end{tabular}

\begin{tabular}{|c|c|c|c|c|}
\hline & \multicolumn{4}{|c|}{ Job satisfaction } \\
\hline & \multicolumn{2}{|c|}{ Media producers } & \multicolumn{2}{|c|}{ Media sellers } \\
\hline & beta & $R^{2}$ & beta & $R^{2}$ \\
\hline Personality & & $.15^{*}$ & & $.34^{*}$ \\
\hline Neuroticism & $-.16^{*}$ & & -.18 & \\
\hline Extroversion & $.17^{*}$ & & $.28^{\circ}$ & \\
\hline Openness & -.08 & & -.01 & \\
\hline Agreeableness & -.02 & & .07 & \\
\hline Conscientiousness & $.13^{*}$ & & .17 & \\
\hline Working conditions & & $.20^{*}$ & & .07 \\
\hline Effort-reward ratio & $-.21^{*}$ & & $-.35^{*}$ & \\
\hline Autonomy & $.38^{*}$ & & .13 & \\
\hline$n$ & & 202 & & 39 \\
\hline Adjusted $R^{2}$ & & $.36^{*}$ & & $.40^{*}$ \\
\hline $\bar{o} p<.1$ & & & & \\
\hline$* p<.05$ & & & & \\
\hline
\end{tabular}

Demographic variables as well as overcommitment did not influence job satisfaction in the initial analysis and were dropped from the regression. Thus, general findings on higher job satisfaction levels among women ${ }^{68}$ could not be replicated. In line with existing research on 
journalists ${ }^{69}$ for media producers, the strongest factor $\left(\mathrm{R}^{2}=.20\right)$ determining job satisfaction is working conditions, with autonomy being most important. More freedom in the decision about when and how to do the work leads to higher job satisfaction. The feeling of not receiving a reward considered deserved significantly reduces the job satisfaction of media producers. This result challenges the assumption of mainly intrinsically motivated media producers.

Although media sellers enjoy more autonomy, the influence of autonomy on job satisfaction is not significant. For them, the effort-reward ratio is more important, suggesting a more tangible and pecuniary approach towards their work. Thus, for them, it is more important to receive a reward they consider to be merited by their effort. The overall relevance of working conditions is higher for media producers and lower for media sellers $\left(\mathrm{R}^{2}=.07\right)$ than for the general working population in Germany $\left(R^{2}=.17\right)$ as reported by Fietze. ${ }^{70}$ Media sellers are similar to the general working population in terms of the relative importance of the effort-reward ratio, while media producers clearly demonstrate a higher relevance of autonomy and lower relevance of expected reward. In this way, the notion of intrinsically motivated creative professionals is confirmed.

For media producers, personality traits have comparatively less explicatory power for job satisfaction $\left(R^{2}=.15\right)$. Three of the five personality traits have significant influence: high neuroticism scores lead to lower job satisfaction, while high extroversion and conscientiousness scores lead to higher job satisfaction.

For the media sellers, all personality traits taken together have rather strong explicatory power $\left(R^{2}=.34\right)$; however, due to the small sample size, only extroversion shows a trend of significant positive effect on job satisfaction. This supports the findings by Barrik and Mount concerning salespeople. ${ }^{71}$ Overall, this study finds fewer personality traits to be influential than Fietze does for the general working population in Germany; 72 however, the significant personality traits show higher standardized coefficients.

To test for interaction effects between working conditions and personality traits, fifteen interaction variables were computed. The regressions for both media producers and media sellers were rerun with these interaction variables, but none of the interaction variables had a significant impact on job satisfaction.

\section{Discussion}

Working conditions are important: the job satisfaction of media producers is strongly driven by autonomy, which confirms the theoretical suggestion by Scott ${ }^{73}$ and Bilton and Leary ${ }^{74}$ about the relevance of autonomy and a "risk space" for creative professionals. In contrast, media sellers rely less on autonomy and are more economic in their motivation since an imbalance of perceived effort and reward reduces their job satisfaction. Personality traits seem to be just as important, with neuroticism (negative) and extroversion (positive) showing the strongest influence. Moreover, the personality traits of media professionals are not as different from the general working population in Switzerland, as anticipated. These results are somewhat in contrast to the work of Fietze, ${ }^{75}$ who found all five personality traits to be important for the job satisfaction of German workers, albeit with a similarly low contribution to the explained variance $\left(R^{2}=.06\right)$. The minute distinctions between the personality profiles of media sellers compared to that of the media producers somewhat contrasts with the findings of Barrick and Mount, 76 who suggest that different jobs call for different personality profiles.

Two explanations can be put forward: first, media occupations are not clearly defined. Usually, one does not need formal qualifications, and in practice, two individuals with the same job title 
might do very different work in different media organizations. Media work is often less professionalized than other occupations; thus, often media professionals need to have a diversified rather than specialized skill set. Second, perceptions of media work as creative work might be misleading. While media production is a creativity-intensive process, much of the daily routine is not creative at all. Thus, a creative personality is only needed for "pockets of creativity."77 During the rest of the time, the relatively high levels of conscientiousness observed might be more helpful in coping with the daily routine. To test whether these explanations hold true, a replication of this study in another media market would be worthwhile. Swiss media organizations are comparatively small and thus have only a limited division of labor. In larger markets with larger organizations, the relationship between personality traits and potentially more specialized job roles might be more pronounced.

Digitization and commercialization have changed the actual work in different media occupations in recent years. Usually, individuals choose jobs that suit their interests and their personalities. If the job changes, chances are that the match between the individual and the job requirements will be affected. Thus, there should be interaction effects between personality traits and work conditions. However, no interaction effects could be found in the regression analysis. This could mean that media professionals are not specialized creatives but rather flexible all-around workers who can easily adapt to changing work conditions. However, studies on photojournalists by Sperlich and Klein-Avraham and Reich describe frictions in the adaptation process. ${ }^{78}$ An alternative explanation of the absence of interaction effects could be found in the composition of the sample. Possibly the "misfits" whose personalities no longer match with the work conditions have already left for another job and are thus not represented in the sample. Eventually, the operationalization of working conditions might be too abstract to capture this change. Therefore, one should not jump to the conclusion that digitization and commercialization did not have an effect on media professional job satisfaction. Rather, the comparison of satisfaction levels between different media occupations suggests that the media sellers who are more profit-oriented and distanced from actual content production show higher levels of satisfaction. On the contrary, the occupation most affected by digitization is closest to art production - photojournalism has the lowest satisfaction levels. From a societal perspective, it seems problematic that jobs with a stronger commercial orientation would be more rewarding than those with a more creative orientation. This can be interpreted as an indicator of a media system that emphasizes financial success over societal utility. Creative media professionals may be not provided with work conditions that they consider satisfying, and thus they might have a lower-than-possible performance.

Strictly speaking, the results of this study are limited to the Swiss media; however, there is no clear indication as to why these results should not apply to other markets. In terms of the comparison with the general working population, some caution is needed because personality traits were not available for all individuals in the SHP - only those who were recently added to the panel. It is not entirely clear whether their reported personality traits are representative of the rest of the Swiss working population.

In this study the actual performance of media professionals was not measured; the argument, rather, relied on generalized results from meta-analysis that established a robust correlation between job satisfaction and performance. ${ }^{79}$ Future research should focus on the question of performance: how can different aspects of performance that relate to different functions of the media be measured adequately? In a commercialized media system, a dominance of the "suits" over the "creatives" can be expected. $8 \square$ Measures of financial performance are easier to 
operationalize than those of societal utility or creative novelty. Extrapolating from the results of this study, job satisfaction and performance are related; however, this connection is mediated by the objective of the job and hence the performance measure. A preliminary conclusion suggests that media organizations with a broader understanding of performance should trust their employees and give them the autonomy they need to be satisfied and thus productive in a societal sense as well.

1 M. Bjørn von Rimscha is Professor of Mass Communication and Media Business at the Johannes Gutenberg University in Mainz (Germany). Before that, he was Senior Research and Teaching Associate at the Institute of Mass Communication and Media Research at the University of Zurich (Switzerland). His most recent book is Medienökonomie (2015) a German-language introduction to media economics together with Gabriele Siegert.

${ }^{2}$ Kate Oakley, "Good Work? Rethinking Cultural Entrepreneurship," in Handbook of Management and Creativity, ed. Chris Bilton and Stephen Cummings (Cheltenham: Elgar, 2014), 145-59.

3 M. B. von Rimscha, Patrik Wikström, and Lucia Naldi, "European Audio-visual Production Companies Adapting to Strategic Challenges," in International Perspectives on Business Innovation and Disruption in the Creative Industries, ed. Robert DeFillippi and Patrik Wikström (Cheltenham: Edward Elgar, 2014), 66-87.

4 Robert G. Picard, "Money, Media, and the Public Interest," in The Press, ed. Geneva Overholser (New York: Oxford University Press, 2005), 337-50.

5 Max Horkheimer and Theodor W. Adorno, Dialektik der Aufklärung (Frankfurt am Main: S. Fischer, 1969).

6 David Hesmondhalgh and Sarah Baker, "Creative Work and Emotional Labour in the Television Industry," Theory, Culture E Society 25, nos. 7-8 (2008): 97-118.

7 Richard E. Caves, Creative Industries: Contracts between Art and Commerce (Cambridge, MA: Harvard University Press, 2000).

8 E.g., Sabina Siebert and Fiona Wilson, "All Work and No Pay: Consequences of Unpaid Work in the Creative Industries," Work, Employment E Society 27, no. 4 (2013), and Neil Percival and David Hesmondhalgh, "Unpaid Work in the UK Television and Film Industries: Resistance and Changing Attitudes," European Journal of Communication 29, no. 2 (2014): 188-203.

9 Joseph A. Schumpeter, Kapitalismus, Sozialismus und Demokratie, 7th ed. (Tübingen: Franke, 1993).

${ }^{10}$ Vincent Mosco, "Brand New World? Globalization, Cyberspace, and the Politics of Convergence," in Public Broadcasting and the Public Interest, ed. Michael P. McCauley et al., Media, Communication, and Culture in America (Armonk, NY: M. E. Sharpe, 2003), 25-40.

${ }^{11}$ Regina Sperlich, “The Mixed Blessing of Autonomy in Digital Cultural Production: A Study on Filmmaking, Press Photography and Architecture in Austria," European Journal of Communication 26, no. 2 (2011): 133-46.

12 Mark Deuze, Media Work. (Cambridge: Polity Press, 2007).

${ }^{13}$ See Russell Cropanzano and Thomas A. Wright, “When a 'Happy' Worker Is Really a 'Productive' Worker: A Review and Further Refinement of the Happy-Productive 
Worker Thesis," Consulting Psychology Journal: Practice and Research 53, no. 3 (2001): 182-99, doi:10.1037/1061-4087.53.3.182, and John M. Zelenski, Steven A. Murphy, and David A. Jenkins, "The Happy-Productive Worker Thesis Revisited," Journal of Happiness Studies 9, no. 4 (2008): 521-37.

${ }^{14}$ Johannes Siegrist, "Adverse Health Effects of High-Effort/Low-Reward Conditions," Journal of Occupational Health Psychology 1, no. 1 (1996): 27-41.

${ }_{15}$ Paul T. Costa Jr. and Robert R. McCrae, "The Revised NEO Personality Inventory (NEO-PI-R)," in The Sage Handbook of Personality Theory and Assessment, ed. Gregory J. Boyle, Gerald Matthews and Donald H. Saklofske, vol. 2, Personality Measurement and Testing (London: Sage, 2008), 179-99.

16 Sarah E. Hampson and Lewis R. Goldberg, "A First Large Cohort Study of Personality Trait Stability over the 40 years between Elementary School and Midlife," Journal of Personality and Social Psychology 91, no. 4 (2006): 763-79.

${ }^{17}$ Fritz J. Roethlisberger and William J. Dickson, Management and the Worker: An Account of a Research Program Conducted by the Western Electric Company, Hawthorne Works, Chicago, 16th ed. (Cambridge, MA: Harvard University Press, 1975).

${ }^{18}$ E.g., Randal A. Beam, "Organizational Goals and Priorities and the Job Satisfaction of US Journalists," Journalism E Mass Communication Quarterly 83, no. 1 (2006): 169-85; Keith Stamm and Doug Underwood, "The Relationship of Job Satisfaction to Newsroom Policy Changes," Journalism \& Mass Communication Quarterly 70, no. 3 (1993): 528-41; George Pollard, "Job Satisfaction among Newsworkers: The Influence of Professionalism, Perceptions of Organizational Structure, and Social Attributes," Journalism \& Mass Communication Quarterly 72, no. 3 (1995): 682-97; and George L. Daniels and C. A. Hollifield, "Times of Turmoil: Short- and Long-Term Effects of Organizational Change on Newsroom Employees," Journalism \& Mass Communication Quarterly 79, no. 3 (2002): 661-80.

19 See, e.g., Barry M. Staw, "Organizational Psychology and the Pursuit of the Happy/Productive Worker," California Management Review 28, no. 4 (1986): 40-53; Barry M. Staw and Sigal G. Barsade, "Affect and Managerial Performance: A Test of the Sadder-but-Wiser vs. Happier-and-Smarter Hypotheses," Administrative Science Quarterly 38, no. 2 (1993): 304-31; Gerald E. Ledford, "Happiness and Productivity Revisited," Journal of Organizational Behavior 20, no. 1 (1999): 25-30; Thomas A. Wright and Barry M. Staw, "Affect and Favorable Work Outcomes: Two Longitudinal Tests of the Happy-Productive Worker Thesis," Journal of Organizational Behavior 20, no. 1 (1999): 1-23; Cropanzano and Wright, "When a 'Happy' Worker Is Really a 'Productive' Worker"; Timothy A. Judge et al., "The Job Satisfaction-Job Performance Relationship: A Qualitative and Quantitative Review," Psychological Bulletin 127, no. 3 (2001): 376-407; and Zelenski, Murphy, and Jenkins, "The Happy-Productive Worker Thesis Revisited,"

${ }^{20}$ See Michael Argyle, "Do Happy Workers Work Harder? The Effect of Job Satisfaction on Job Performance," in How Harmful Is Happiness? Consequences of Enjoying Life or Not, ed. Ruut Veenhoven (Rotterdam: Universitaire Pers Rotterdam, 1989); Judge et al., "The Job Satisfaction-Job Performance Relationship." While not referring to a psychological perspective on "happiness," recent studies on media work have expounded upon the problems of the term. Case studies like the one presented by 
Hesmondhalgh and Baker, "Creative Work and Emotional Labour," contrast fun during production with a generally precarious working condition.

${ }^{21}$ See Toon W. Taris and Paul J. Schreurs, "Well-Being and Organizational Performance: An Organizational-Level Test of the Happy-Productive Worker Hypothesis," Work $\mathcal{E}$ Stress 23, no. 2 (2009): 120-36, and Thomas A. Wright and Russell Cropanzano, "The Role of Psychological Well-Being in Job Performance: A Fresh Look at an Age-Old Quest," Organizational Dynamics 33, no. 4 (2004): 338-51.

${ }^{22}$ See Sonja Lyubomirsky, Laura King, and Ed Diener, "The Benefits of Frequent Positive Affect: Does Happiness Lead to Success?," Psychological Bulletin 131, no. 6 (2005): 80355, and Wright and Staw, "Affect and Favorable Work Outcomes."

${ }^{23}$ Zelenski, Murphy, and Jenkins, "The Happy-Productive Worker Thesis Revisited."

${ }^{24}$ Cynthia D. Fisher, "Why Do Lay People Believe That Satisfaction and Performance Are Correlated? Possible Sources of a Commonsense Theory," Journal of Organizational Behavior 24, no. 6 (2003): 753-77.

${ }^{25}$ M. M. Petty, G. W. McGee, and J. W. Cavender, “A Meta-Analysis of the Relationships Between Individual Job Satisfaction and Individual Performance," Academy of Management Review 9, no. 4 (1984): 712-21; Judge et al., “The Job Satisfaction-Job Performance Relationship."

${ }^{26}$ See Arnold B. Bakker and Evangelia Demerouti, “The Job Demands-Resources Model: State of the Art," Journal of Managerial Psychology 22, no. 3 (2007): 309-28, and Stephen E. Humphrey, Jennifer D. Nahrgang, and Frederick P. Morgeson, "Integrating Motivational, Social, and Contextual Work Design Features: A Meta-analytic Summary and Theoretical Extension of the Work Design Literature," Journal of Applied Psychology 92, no. 5 (2007): 1332-56.

${ }^{27}$ Murray R. Barrick and Michael K. Mount, “The Big Five Personality Dimensions and Job Performance: A Meta-analysis," Personnel Psychology 44, no. 1 (1991): 1-26.

28 Joyce Hogan and Brent Holland, "Using Theory to Evaluate Personality and JobPerformance Relations: A Socioanalytic Perspective," Journal of Applied Psychology 88, no. 1 (2003): 100-12.

29 Timothy A. Judge, Daniel Heller, and Michael K. Mount, "Five-Factor Model of Personality and Job Satisfaction: A Meta-analysis," Journal of Applied Psychology 87, no. 3 (2002): 376-407.

${ }^{30}$ Barrick and Mount, "The Big Five Personality Dimensions and Job Performance."

${ }^{31}$ Andreas Rauch and Michael Frese, "Let's Put the Person Back into Entrepreneurship Research: A Meta-analysis on the Relationship Between Business Owners' Personality Traits, Business Creation, and Success," European Journal of Work and Organizational Psychology 16, no. 4 (2007): 353-86.

${ }^{32}$ Nora Madjar, Greg R. Oldham, and Michael G. Pratt, “There's No Place Like Home? The Contributions of Work and Nonwork Creativity Support to Employees' Creative Performance," Academy of Management Journal 45, no. 4 (2002): 757-67.

${ }^{33}$ Christopher Robert and Yu H. Cheung, "An Examination of the Relationship Between Conscientiousness and Group Performance on a Creative Task," Journal of Research in Personality 44, no. 2 (2010): 221-31.

34 Susan Sung Eun Chung and Jason Meneely, "Profiling Group Dynamics within Business and Design Student Teams: Relationships among Personality Traits, Problem- 
Solving Styles, and Creative Performance," Journal of Interior Design 37, no. 3 (2012): 23-45.

35 Caves, Creative Industries.

${ }^{36}$ Susan Strickland and Annette Towler, "Correlates of Creative Behaviour: The Role of Leadership and Personal Factors," Canadian Journal of Administrative Sciences 28, no. 1 (2011): 41-51.

37 John Schaubroeck, Daniel C. Ganster, and James R. Jones, “Organization and Occupation Influences in the Attraction-Selection-Attrition Process," Journal of Applied Psychology 83, no. 6 (1998): 869-91.

38 Jeanine M. Williamson, John W. Lounsbury, and Lee D. Han, “Key Personality Traits of Engineers for Innovation and Technology Development," Journal of Engineering and Technology Management 30, no. 2 (2013): 157-68.

${ }^{39}$ von Rimscha, Wikström, and Naldi, "European Audio-Visual Production Companies Adapting to Strategic Challenges."

40 Stamm and Underwood, "The Relationship of Job Satisfaction to Newsroom Policy Changes."

${ }^{41}$ See, e.g., Kathleen M. Ryan, "The Performative Journalist: Job Satisfaction, Temporary Workers and American Television News," Journalism 10, no. 5 (2009): 647-64, and Lori A. Bergen and David H. Weaver, "Job Satisfaction of Daily Newspaper Journalists and Organization Size," Newspaper Research Journal 9, no. 2 (1988): 1-13.

${ }^{42}$ Ronald J. Burke and Stig Matthiesen, "Workaholism among Norwegian Journalists: Antecedents and Consequences," Stress and Health 20, no. 5 (2004): 301-8.

43 A. N. Ofili et al., "Assessment of Job Satisfaction, Job Stress and Psychological Health Of Journalists in South-South, Nigeria," International Journal of Medicine and Biomedical Research 3, no. 3 (2014): 209-18.

${ }^{44} \mathrm{M}$. Bjørn von Rimscha and Gabriele Siegert, Medienökonomie: Eine problemorientierte Einführung (Wiesbaden: Springer VS, 2015).

45 See, e.g., Karl E. Rosengren, Mats Carlson, and Yael Tågerud, "Quality in Programming: Views From the North," Studies in Broadcasting 27 (1991): 21-80; Irene Costera Meijer, "The Public Quality of Popular Journalism: Developing a Normative Framework," Journalism Studies 2, no. 2 (2001): 189-205; Wolfgang Seufert, "Programmaufwand, Qualität und Wirtschaftlichkeit öffentlich-rechtlicher Rundfunkangebote," Medien E Kommunikationswissenschaft 54, no. 3 (2006): 365-85; and Harald Rau, Qualität in einer Ökonomie der Publizistik: Betriebswirtschaftliche Lösungen für die Redaktion (Wiesbaden: VS Verlag, 2007).

${ }^{46}$ Simon Fietze, "Arbeitszufriedenheit und Persönlichkeit: 'Wer schaffen will, muss fröhlich sein!'” SOEP papers 388 (2011).

47The Swiss Household Panel is a survey conducted within the framework of the Swiss Foundation for Research in Social Sciences (FORS) and funded by the Swiss National Science Foundation.

${ }^{48}$ Heide Glaesmer et al., "The German Version of the Satisfaction with Life Scale (SWLS)," European Journal of Psychological Assessment 27, no. 2 (2011): 127-32.

${ }^{49}$ Ed Diener et al., "The Satisfaction with Life Scale," Journal of Personality Assessment 49, no. 1 (1985): 71-75.

50 Jochen Fahrenberg et al., Fragebogen zur Lebenszufriedenheit (FLZ): Handweisung (Göttingen: Horgrefe, 2000) 
51 E.g., Fietze, "Arbeitszufriedenheit und Persönlichkeit" and Michael Ertel et al., "Adverse Psychosocial Working Conditions and Subjective Health in Freelance Media Workers," Work \& Stress 19, no. 3 (2005): 293-99.

52 Sebastian Stegmann et al., "Der Work Design Questionnaire: Vorstellung und Erste Validierung Einer Deutschen Version," Zeitschrift für Arbeits- und Organisationspsychologie AEO 54, no. 1 (2010): 1-28.

${ }^{53}$ Frederick P. Morgeson and Stephen E. Humphrey, "The Work Design Questionnaire (WDQ): Developing and Validating a Comprehensive Measure for Assessing Job Design and the Nature of Work," Journal of Applied Psychology 91, no. 6 (2006): 1321-39.

54 Arbeitsstelle für Vergleichende Gesellschaftsgeschichte, Europäische Konsumgeschichte: Zur Gesellschafts- und Kulturgeschichte des Konsums (18. bis 20. Jahrhundert) (Frankfurt am Main: Campus, 1997).

55 Beatrice Rammstedt and Oliver P. John, "Kurzversion des Big Five Inventory (BFI-K)," Diagnostica 51, no. 4 (2005):195-206.

56 Kathrin Junghanns and Thomas Hanitzsch, "Deutsche Auslandskorrespondenten im Profil," Medien E Kommunikationswissenschaft 54, no. 3 (2006): 412-29.

57 See, e.g., Ulf Hannerz, Foreign News: Exploring the World of Foreign Correspondents 2000 (Chicago: University of Chicago Press, 2004) and Angela Dressler, Nachrichtenwelten: Hinter den Kulissen der Auslandsberichterstattung / eine Ethnographie (Bielefeld: Transcript, 2008).

58 John Freeman, "Personality as an Indicator of Success: A Study of NPPA Contest Winners," Visual Communication Quarterly 11, nos. 1-2 (2004): 18-22.

${ }^{59}$ Laura Grindstaff, The Money Shot: Trash, Class, and the Making of TV Talk Shows (Chicago: University of Chicago Press, 2002).

60 Marianna Patrona, "Conversationalization and Media Empowerment in Greek Television Discussion Programs," Discourse E Society 17, no. 1 (2006): 15.

${ }^{61}$ Gil Greengross and Geoffrey F. Miller, "The Big Five Personality Traits of Professional Comedians Compared to Amateur Comedians, Comedy Writers, and College Students," Personality and Individual Differences 47, no. 2 (2009): 79-83.

62 Doug Underwood, When MBAs Rule the Newsroom: How the Marketers and Managers Are Reshaping Today's Media (New York: Columbia University Press, 1993).

${ }^{63}$ Barrick and Mount, "The Big Five Personality Dimensions and Job Performance."

${ }^{64}$ J. R. Hackman and Greg R. Oldham, "Motivation through the Design of Work: Test of a Theory," Organizational Behavior and Human Performance 16, no. 2 (1976): 250-79.

65 Richard L. Kohr and Paul A. Games, "Robustness of the Analysis of Variance, the Welch Procedure and a Box Procedure to Heterogeneous Variances," Journal of Experimental Education 43, no. 1 (1974): 61-69.

66 Sperlich, "The Mixed Blessing of Autonomy in Digital Cultural Production," and Inbal Klein-Avraham and Zvi Reich, "Out of the Frame: A Longitudinal Perspective on Digitization and Professional Photojournalism," New Media E Society (2014): n. p.

${ }^{67}$ Zhou Xiao, "How Digital Technology Impacts International News Communication: From Integrated Cost to Power Structure," in International News in the Digital Age: EastWest Perceptions of a New World Order, ed. Judith Clarke and Michael L Bromley (New York: Routledge, 2012).

68 Andrew E. Clark, "Job Satisfaction and Gender: Why Are Women so Happy at Work?," Labour Economics 4, no. 4 (1997): 341-72. 
${ }^{69}$ David H. Weaver and G. Cleveland Wilhoit, The American Journalist in the 1990s: US News People at the End of an Era (Mahwah, NJ: Lawrence Erlbaum, 1996).

7ロFietze, "Arbeitszufriedenheit und Persönlichkeit."

7>Barrick and Mount, "The Big Five Personality Dimensions and Job Performance."

7ロFietze, "Arbeitszufriedenheit und Persönlichkeit."

$7 \square$ Randall K. Scott, "Creative Employees: A Challenge to Managers," Journal of Creative Behavior 29, no. 1 (1995): 64-71.

$7 \square$ Chris Bilton and Ruth Leary, "What Can Managers Do for Creativity? Brokering Creativity in the Creative Industries," International Journal of Cultural Policy 8, no. 1 (2002): 59.

7>Fietze, "Arbeitszufriedenheit und Persönlichkeit."

7\Barrick and Mount, "The Big Five Personality Dimensions and Job Performance."

$7 \square$ Stefan Seidel, Felix Müller-Wienbergen, and Michael Rosemann, "Pockets of Creativity in Business Processes," Communications of the Association for Information Systems 27, no. 8 (2010): 415-36.

$\square$ Sperlich, "The Mixed Blessing of Autonomy in Digital Cultural Production," and Klein-Avraham and Reich, "Out of the Frame."

$\square$ Petty, McGee, and Cavender, "A Meta-analysis of the Relationships between Individual Job Satisfaction and Individual Performance," and Judge et al., "The Job Satisfaction-Job Performance Relationship."

$\square$ Bob Hughes, "'Suits' and 'Creatives': Managerial Control, the Expropriation of Fun and the Manufacture of Consent," Work Organisation, Labour E Globalisation 1, no. 1 (2007): 76-88.

\section{Bibliography}

Arbeitsstelle für Vergleichende Gesellschaftsgeschichte. Europäische Konsumgeschichte: Zur Gesellschafts- und Kulturgeschichte des Konsums (18. bis 20. Jahrhundert). Frankfurt am Main: Campus, 1997.

Argyle, Michael. “Do Happy Workers Work Harder? The Effect of Job Satisfaction on Job Performance." In How Harmful Is Happiness? Consequences of Enjoying Life or Not, edited by Ruut Veenhoven, 94-105. Rotterdam: Universitaire Pers Rotterdam, 1989.

Bakker, Arnold B., and Evangelia Demerouti. "The Job Demands-Resources Model: State of the Art." Journal of Managerial Psychology 22, no. 3 (2007): 309-28.

Barrick, Murray R., and Michael K. Mount. “The Big Five Personality Dimensions and Job Performance: A Meta-analysis." Personnel Psychology 44, no. 1 (1991): 1-26.

Beam, Randal A. "Organizational Goals and Priorities and the Job Satisfaction of US Journalists." Journalism E Mass Communication Quarterly 83, no. 1 (2006): 169-85. 
Bergen, Lori A., and David H. Weaver. "Job Satisfaction of Daily Newspaper Journalists and Organization Size." Newspaper Research Journal 9, no. 2 (1988): 1-13.

Bilton, Chris, and Ruth Leary. "What Can Managers Do for Creativity? Brokering Creativity in the Creative Industries." International Journal of Cultural Policy 8, no. 1 (2002): 49-64.

Burke, Ronald J., and Stig Matthiesen. "Workaholism among Norwegian Journalists: Antecedents and Consequences." Stress and Health 20, no. 5 (2004): 301-8.

Caves, Richard E. Creative Industries: Contracts between Art and Commerce. Cambridge, MA: Harvard University Press, 2000.

Clark, Andrew E. “Job Satisfaction and Gender: Why Are Women So Happy at Work?" Labour Economics 4, no. 4 (1997): 341-72.

Costa, Paul T., Jr., and Robert R. McCrae. "The Revised NEO Personality Inventory (NEO-PIR)." In The Sage Handbook of Personality Theory and Assessment: Volume 2 - Personality Measurement and Testing, edited by Gregory J. Boyle, Gerald Matthews and Donald H. Saklofske, 179-99. London: Sage, 2008.

Costera Meijer, Irene. “The Public Quality of Popular Journalism: Developing a Normative Framework." Journalism Studies 2, no. 2 (2001): 189-205.

Cropanzano, Russell, and Thomas A. Wright. "When a 'Happy' Worker Is Really a 'Productive' Worker: A Review and Further Refinement of the Happy-Productive Worker Thesis." Consulting Psychology Journal: Practice and Research 53, no. 3 (2001): 182-99. doi:10.1037/1061-4087.53.3.182.

Daniels, George L., and C. A. Hollifield. "Times of Turmoil: Short- and Long-Term Effects of Organizational Change on Newsroom Employees." Journalism \& Mass Communication Quarterly 79, no. 3 (2002): 661-80.

Deuze, Mark. Media Work. Cambridge: Polity Press, 2007.

Diener, Ed, Robert A. Emmons, Randy J. Larsen, and Sharon Griffin. “The Satisfaction with Life Scale." Journal of Personality Assessment 49, no. 1 (1985): 71-75.

Dressler, Angela. Nachrichtenwelten: Hinter den Kulissen der Auslandsberichterstattung / eine Ethnographie. Bielefeld: Transcript, 2008.

Ertel, Michael, Eberhard Pech, Peter Ullsperger, Von Dem Knesebeck, Olaf, and Johannes Siegrist. "Adverse Psychosocial Working Conditions and Subjective Health in Freelance Media Workers." Work $\mathcal{E}$ Stress 19, no. 3 (2005): 293-99. doi:10.1080/02678370500307289.

Fahrenberg, Jochen, Michael Myrtek, Jörg Schumacher, and Elmar Brähler. Fragebogen zur Lebenszufriedenheit (FLZ): Handweisung. Göttingen: Horgrefe, 2000. 
Fietze, Simon. “Arbeitszufriedenheit und Persönlichkeit: 'Wer Schaffen Will, Muss Fröhlich Sein!'." SOEP papers 388, 2011.

Fisher, Cynthia D. "Why Do Lay People Believe That Satisfaction and Performance Are Correlated? Possible Sources of a Commonsense Theory." Journal of Organizational Behavior 24, no. 6 (2003): 753-77.

Freeman, John. "Personality as an Indicator of Success: A study of NPPA Contest Winners." Visual Communication Quarterly 11, 1-2 (2004): 18-22.

Glaesmer, Heide, Gesine Grande, Elmar Braehler, and Marcus Roth. "The German Version of the Satisfaction with Life Scale (SWLS)." European Journal of Psychological Assessment 27, no. 2 (2011): 127-32.

Greengross, Gil, and Geoffrey F. Miller. “The Big Five Personality Traits of Professional Comedians Compared to Amateur Comedians, Comedy Writers, and College Students." Personality and Individual Differences 47, no. 2 (2009): 79-83. doi:10.1016/j.paid.2009.01.045.

Grindstaff, Laura. The Money Shot: Trash, Class, and the Making of TV Talk Shows. Chicago: University of Chicago Press, 2002.

Hackman, J. R., and Greg R. Oldham. "Motivation through the Design of Work: Test of a Theory." Organizational Behavior and Human Performance 16, no. 2 (1976): 250-79.

Hampson, Sarah E., and Lewis R. Goldberg. "A First Large Cohort Study of Personality Trait Stability over the 40 Years between Elementary School and Midlife." Journal of Personality and Social Psychology 91, no. 4 (2006): 763-79.

Hannerz, Ulf. Foreign News: Exploring the World of Foreign Correspondents 2000. Chicago: University of Chicago Press, 2004.

Hesmondhalgh, David, and Sarah Baker. "Creative Work and Emotional Labour in the Television Industry." Theory, Culture \& Society 25, 7-8 (2008): 97-118.

Hogan, Joyce, and Brent Holland. "Using Theory to Evaluate Personality and Job-Performance Relations: A Socioanalytic Perspective." Journal of Applied Psychology 88, no. 1 (2003): 100-112.

Horkheimer, Max, and Theodor W. Adorno. Dialektik der Aufklärung. Frankfurt am Main: S. Fischer, 1969.

Hughes, Bob. "'Suits' and 'Creatives': Managerial Control, the Expropriation of Fun and the Manufacture of Consent." Work Organisation, Labour \& Globalisation 1, no. 1 (2007): 7688.

Humphrey, Stephen E., Jennifer D. Nahrgang, and Frederick P. Morgeson. “Integrating Motivational, Social, and Contextual Work Design Features: A Meta-analytic Summary 
and Theoretical Extension of the Work Design Literature." Journal of Applied Psychology 92, no. 5 (2007): 1332-56.

Judge, Timothy A., Daniel Heller, and Michael K. Mount. “Five-Factor Model of Personality and Job Satisfaction: A Meta-analysis." Journal of Applied Psychology 87, no. 3 (2002): 530-41.

Judge, Timothy A., Carl J. Thoresen, Joyce E. Bono, and Gregory K. Patton. "The Job Satisfaction-Job Performance Relationship: A Qualitative and Quantitative Review." Psychological Bulletin 127, no. 3 (2001): 376-407.

Junghanns, Kathrin, and Thomas Hanitzsch. "Deutsche Auslandskorrespondenten im Profil." Medien E Kommunikationswissenschaft 54, no. 3 (2006): 412-29.

Klein-Avraham, Inbal, and Zvi Reich. "Out of the Frame: A Longitudinal Perspective on Digitization and Professional Photojournalism." New Media E Society (2014): n. p.

Kohr, Richard L., and Paul A. Games. "Robustness of the Analysis of Variance, the Welch Procedure and a Box Procedure to Heterogeneous Variances." Journal of Experimental Education 43, no. 1 (1974): 61-69.

Ledford, Gerald E. "Happiness and Productivity Revisited." Journal of Organizational Behavior 20, no. 1 (1999): 25-30.

Lyubomirsky, Sonja, Laura King, and Ed Diener. “The Benefits of Frequent Positive Affect: Does Happiness Lead to Success?" Psychological Bulletin 131, no. 6 (2005): 803-55.

Madjar, Nora, Greg R. Oldham, and Michael G. Pratt. “There's No Place Like Home? The Contributions of Work and Nonwork Creativity Support to Employees' Creative Performance." Academy of Management Journal 45, no. 4 (2002): 757-67.

Morgeson, Frederick P., and Stephen E. Humphrey. “The Work Design Questionnaire (WDQ): Developing and Validating a Comprehensive Measure for Assessing Job Design and the Nature of Work." Journal of Applied Psychology 91, no. 6 (2006): 1321-39.

Mosco, Vincent. "Brand New World? Globalization, Cyberspace, and the Politics of Convergence." In Public Broadcasting and the Public Interest, edited by Michael P. McCauley et al., 25-40. Armonk, NY: M. E. Sharpe, 2003.

Oakley, Kate. "Good Work? Rethinking Cultural Entrepreneurship." In Handbook of Management and Creativity, edited by Chris Bilton and Stephen Cummings, 145-59. Cheltenham: Elgar, 2014.

Ofili, A. N., E. A. Tobin, M. A. Ilombu, E. O. Igbinosun, and I. Iniomor. “Assessment of Job Satisfaction, Job Stress and Psychological Health of Journalists in South-South, Nigeria." International Journal of Medicine and Biomedical Research 3, no. 3 (2014): 209-18.

Patrona, Marianna. "Conversationalization and Media Empowerment in Greek Television Discussion Programs." Discourse E Society 17, no. 1 (2006): 5-27. 
Percival, Neil, and David Hesmondhalgh. "Unpaid Work in the UK Television and Film Industries: Resistance and Changing Attitudes." European Journal of Communication 29, no. 2 (2014): 188-203.

Petty, M. M., G. W. McGee, and J. W. Cavender. "A Meta-analysis of the Relationships Between Individual Job Satisfaction and Individual Performance." Academy of Management Review 9, no. 4 (1984): 712-21.

Picard, Robert G. "Money, Media, and the Public Interest." In The Press, edited by Geneva Overholser, 337-50. New York: Oxford University Press, 2005.

Pollard, George. "Job Satisfaction Among Newsworkers: The Influence of Professionalism, Perceptions of Organizational Structure, and Social Attributes." Journalism \& Mass Communication Quarterly 72, no. 3 (1995): 682-97.

Rammstedt, Beatrice, and Oliver P. John. "Kurzversion des Big Five Inventory (BFI-K)." Diagnostica 51, no. 4 (2005): 195-206. doi:10.1026/0012-1924.51.4.195.

Rau, Harald. Qualität in einer Ökonomie der Publizistik: Betriebswirtschaftliche Lösungen für die Redaktion. Wiesbaden: VS Verlag, 2007. doi:10.1007/978-3-531-90415-3.

Rauch, Andreas, and Michael Frese. "Let's Put the Person Back into Entrepreneurship Research: A Meta-analysis on the Relationship between Business Owners' Personality Traits, Business Creation, and Success." European Journal of Work and Organizational Psychology 16, no. 4 (2007): 353-85.

Robert, Christopher, and Yu H. Cheung. "An Examination of the Relationship Between Conscientiousness and Group Performance on a Creative Task." Journal of Research in Personality 44, no. 2 (2010): 222-31.

Roethlisberger, Fritz J., and William J. Dickson. Management and the Worker: An Account of a Research Program Conducted by the Western Electric Company, Hawthorne Works, Chicago. 1934. 16th ed. Cambridge, MA: Harvard University Press, 1975.

Rosengren, Karl E., Mats Carlson, and Yael Tågerud. "Quality in programming: Views from the North." Studies in Broadcasting 27 (1991): 21-80.

Ryan, Kathleen M. "The Performative Journalist: Job Satisfaction, Temporary Workers and American Television News." Journalism 10, no. 5 (2009): 647-64.

Schaubroeck, John, Daniel C. Ganster, and James R. Jones. "Organization and Occupation Influences in the Attraction-Selection-Attrition Process." Journal of Applied Psychology 83, no. 6 (1998): 869-91.

Schumpeter, Joseph A. Kapitalismus, Sozialismus und Demokratie. 1942. 7th ed. Tübingen: Franke, 1993.

Scott, Randall K. "Creative Employees: A Challenge to Managers." Journal of Creative Behavior 29, no. 1 (1995): 64-71. 
Seidel, Stefan, Felix Müller-Wienbergen, and Michael Rosemann. "Pockets of Creativity in Business Processes." Communications of the Association for Information Systems 27, no. 8 (2010): 415-36.

Seufert, Wolfgang. "Programmaufwand, Qualität und Wirtschaftlichkeit öffentlich-rechtlicher Rundfunkangebote." Medien E Kommunikationswissenschaft 54, no. 3 (2006): 365-85.

Siebert, Sabina, and Fiona Wilson. "All Work and No Pay: Consequences of Unpaid Work in the Creative Industries." Work, Employment \& Society 27, no. 4 (2013): 711-21. doi:10.1177/0950017012474708.

Siegrist, Johannes. "Adverse Health Effects of High-Effort/Low-Reward Conditions." Journal of Occupational Health Psychology 1, no. 1 (1996): 27-41.

Sperlich, Regina. "The Mixed Blessing of Autonomy in Digital Cultural Production: A Study on Filmmaking, Press Photography and Architecture in Austria." European Journal of Communication 26, no. 2 (2011): 133-46.

Stamm, Keith, and Doug Underwood. “The Relationship of Job Satisfaction to Newsroom Policy Changes." Journalism E Mass Communication Quarterly 70, no. 3 (1993): 528-41.

Staw, Barry M. "Organizational Psychology and the Pursuit of the Happy/Productive Worker." California Management Review 28, no. 4 (1986): 40-53.

Staw, Barry M., and Sigal G. Barsade. "Affect and Managerial Performance: A Test of the Sadder-aut-Wiser vs. Happier-and-Smarter Hypotheses." Administrative Science Quarterly 38, no. 2 (1993): 304-31.

Stegmann, Sebastian, Rolf van Dick, Johannes Ullrich, Julie Charalambous, Birgit Menzel, Nikolai Egold, and Tina T.-C. Wu. "Der Work Design Questionnaire: Vorstellung und Erste Validierung Einer Deutschen Version." Zeitschrift für Arbeits- und Organisationspsychologie AEO 54, no. 1 (2010): 1-28.

Strickland, Susan, and Annette Towler. "Correlates of Creative Behaviour: The Role of Leadership and Personal Factors." Canadian Journal of Administrative Sciences 28, no. 1 (2011): 41-51.

Sung Eun Chung, Susan, and Jason Meneely. "Profiling Group Dynamics within Business and Design Student Teams: Relationships among Personality Traits, Problem-Solving Styles, and Creative Performance." Journal of Interior Design 37, no. 3 (2012): 23-45.

Taris, Toon W., and Paul J. Schreurs. "Well-Being and Organizational Performance: An Organizational-Level Test of the Happy-Productive Worker Hypothesis." Work E Stress 23, no. 2 (2009): 120-36.

Underwood, Doug. When MBAs Rule the Newsroom: How the Marketers and Managers Are Reshaping Today's Media. New York: Columbia University Press, 1993. 
von Rimscha, M. B., and Gabriele Siegert. Medienökonomie: Eine Problemorientierte Einführung. Wiesbaden: Springer VS, 2015. doi:10.1007/978-3-531-18802-7.

von Rimscha, M. B., Patrik Wikström, and Lucia Naldi. "European Audio-Visual Production Companies Adapting to Strategic Challenges." In International Perspectives on Business Innovation and Disruption in the Creative Industries, edited by Robert DeFillippi and Patrik Wikström, 66-87. Cheltenham: Edward Elgar, 2014.

Weaver, David H., and G. C. Wilhoit. The American Journalist in the 1990s: US News People at the End of an Era. Mahwah, NJ: Lawrence Erlbaum, 1996.

Williamson, Jeanine M., John W. Lounsbury, and Lee D. Han. "Key Personality Traits of Engineers for Innovation and Technology Development." Journal of Engineering and Technology Management 30, no. 2 (2013): 157-68.

Wright, Thomas A., and Russell Cropanzano. "The Role of Psychological Well-Being in Job Performance: A Fresh Look at an Age-Old Quest." Organizational Dynamics 33, no. 4 (2004): 338-51.

Wright, Thomas A., and Barry M. Staw. "Affect and Favorable Work Outcomes: Two Longitudinal Tests of the Happy-Productive Worker Thesis." Journal of Organizational Behavior 20, no. 1 (1999): 1-23.

Xiao, Zhou. "How Digital Technology Impacts International News Communication: From Integrated Cost to Power Structure." In International News in the Digital Age: East-West Perceptions of a New World Order, edited by Judith Clarke and Michael L Bromley, 60-74. New York: Routledge, 2012.

Zelenski, John M., Steven A. Murphy, and David A. Jenkins. “The Happy-Productive Worker Thesis Revisited." Journal of Happiness Studies 9, no. 4 (2008): 521-37.

\section{(cc) Br-No-ND}

Copyright (c) 2015 (M. Bjørn von Rimscha). Media Industries is an open-access, peer-reviewed, online academic journal. As such, we aim to participate in the open exchange of information. This work is licensed under a Creative Commons Attribution Noncommercial No Derivatives (by-nc-nd) License. Under this license, this work is available for sharing and noncommercial distribution provided the appropriate attribution is given. 